\title{
A Strategic Approach to the Transformation of Czech Highway Administration
}

K. Pospíšil*, D. Mečiarová

CDV - Transport Research Centre

*Corresponding author: karel.pospisil@cdv.cz

\author{
A. Hanzelková, M. Keřkovský \\ B.I.B.S., a.s. (Brno International Business School)
}

DOI: 10.2478/v10158-012-0012-5

\begin{abstract}
Studies of the current condition of management in the Czech Republic show, that strategic management is one of the greatest weaknesses in the management of Czech businesses when compared with their western competitors. The intended transformation of the Czech highway administration from the existing state allowance organisation to a company with a new legal status is an excellent opportunity to design a strategically oriented and well-organised body which will be capable to be effective in strategic development, investment, maintenance, and operation of the managed highway network. At the Brno International Business School considerable attention has been paid to studying strategic business management over the last ten years. It supports the effort of the CDV Transport Research Centre to achieve a holistic approach to the strategic development of the transportation sector. The paper describes a possible way for drafting a strategy concept for transforming the highway administration.
\end{abstract}

\section{INTRODUCTION}

The existing situation concerning the management and funding of the transport infrastructure is currently unsatisfactory. The major task in this area is carried out by the Road and Motorway Directorate of the Czech Republic (ǨSD) - the highway administration, which still has the legal status of a state allowance organization. It is a body responsible for investment, construction, modernisation, maintenance, and reconstruction of the motorways and primary rural roads in the Czech Republic.

The legal status of a state allowance organization is currently considered unfavourable particularly in the following areas:

a) insufficient flexibility,

b) labour legislation limitations,

c) impossibility to deduct VAT,

d) financial limits.

Ad a) Insufficient flexibility is given by the existing legal status of the allowance organization. At the moment, the highway administration is managed by a general director directly appointed by the minister of transport. The activities of the organization are funded by an allowance provided by the State Fund for Transport Infrastructure (SFDI) 
on a contractual basis from the state budget of the Czech Republic, international institutions' funds, and other financial sources.

Ad b) At the moment, the remuneration system is based on a governmental grades system which is not able to be motivating enough. A change in legal status from the existing state organization will allow it to adopt its own tailored remuneration motivating system.

Furthermore, the legal status change could lead to depoliticization and a release from the relationships with the Ministry of Transport, which is based upon the fact that the organizational structure of a joint stock company is, according to Commercial Code, far better in reflecting the needs for these types of activities.

Ad c) In the case of the highway administration becoming a full VAT payee, all construction costs would be reduced by the current VAT rate, which the highway administration may claim.

Ad d) This area includes the much simpler possibility to issue bonds to provide funds for individual projects lacking public funds, project loans, and co-operation with the private sector, and the possibility to be more flexible in the support of individual projects.

Due to the above mentioned problems, which are currently having a negative impact on ŘSD, the currently considered transition of $\breve{\mathrm{RSD}}$ as a state allowance organization to an entity with a different legal status will definitely be a positive step towards the new funding of the transport infrastructure in the Czech Republic.

\section{SENSE OF STRATEGY}

There are several models for designing the strategy of a company. These models use the notion "strategy" either as a way of achieving the intended target, e.g. Kotler (1984), Johnson and Scholes (1993) etc., or as a long-time plan, as described by Dobson and Starkey (1993).

A wider understanding of strategy is presented by Nickols (2000). He states that there are at least three basic forms of strategy in the business world, such as: (1) strategy or "strategy in general," (2) corporate strategy and (3) competitive strategy. The relationship between the above-mentioned forms of strategy is shown in Figure 1.

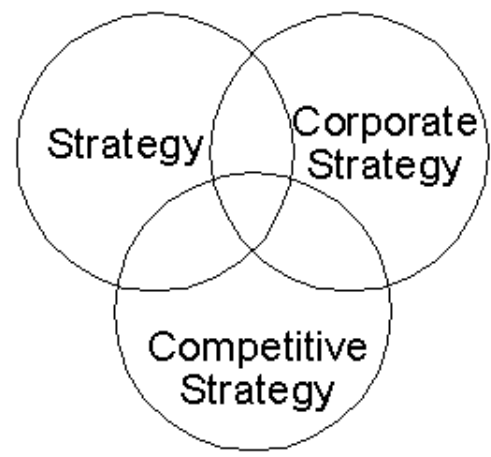

Figure 1: Three Forms of Strategy (Nickols, 2000).

Nickols (2000) highlights that there are many definitions of strategy found in management literature which fall into one of four categories: plan, pattern, position, and perspective.

According to these views, strategy is:

- A plan, "how" means of getting from here to there;

- A pattern in actions over time; for example, a company that regularly markets very expensive products is using a "high end" strategy; 
- A position, i.e., it reflects the decisions to offer particular products or services in particular markets; and

- A perspective, i.e., a vision and direction, a view of what the company or organization is to become.

Nickols summarises accordingly with of Porter (1996) that strategy in general is concerned with the how, with the courses of action intended to achieve particular objectives. Corporate strategy is concerned with the choices and commitments regarding markets, business, and the very nature of the company itself. Competitive strategy is concerned with competitors and the basis of competition. These basic points are illustrated in Figure 2.

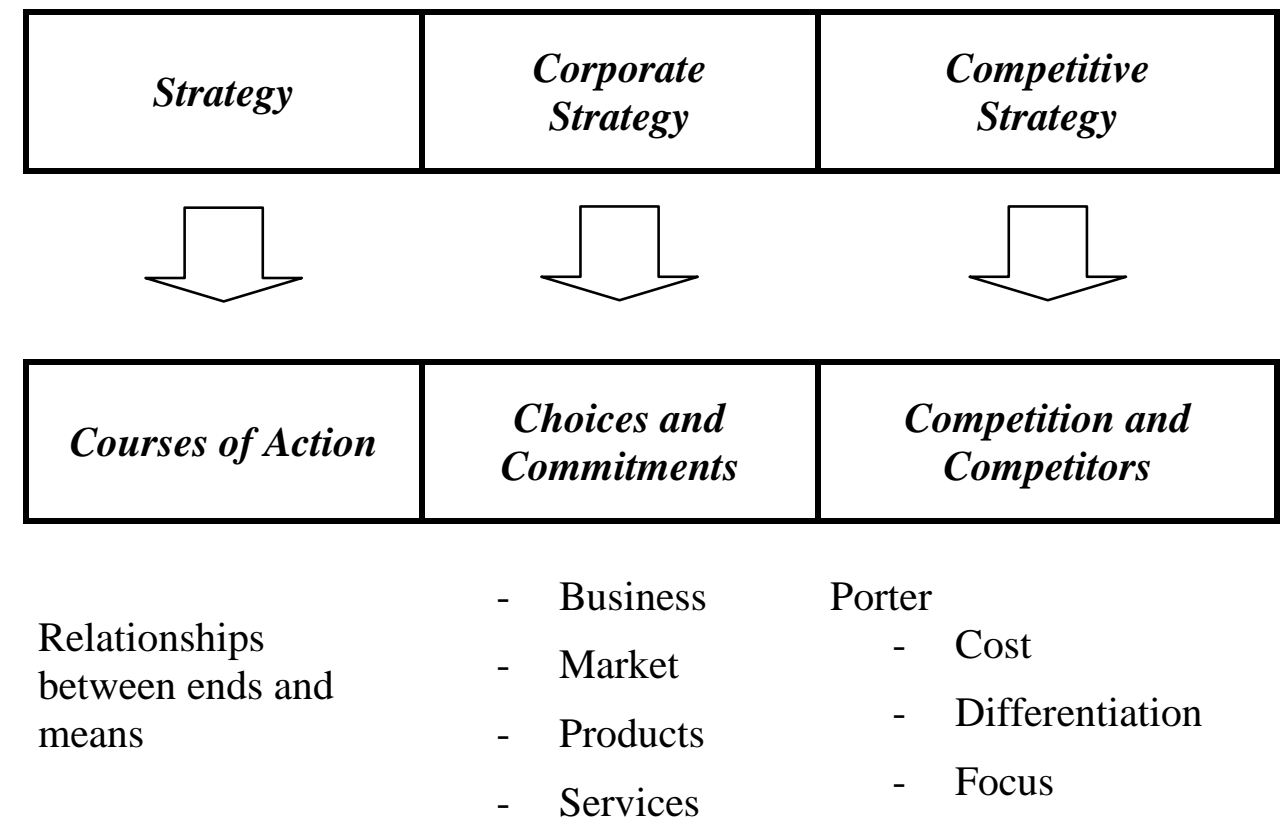

Figure 2: Focal Points of Strategy (Nickols, 2000).

The introduced approach to strategy formulation uses the Keřkovský and Vykypěl (2006) concept of stratifying strategy into three-level-model of strategies:

- corporate strategy,

- business strategy,

- functional strategy.

\section{USED METHODS}

\subsection{Hierarchy of Company Strategies}

As shown at the end of the introductory part, the model selected operates with three levels of strategies in a company. The structure and main characteristics of these are visible in Figure 3. 


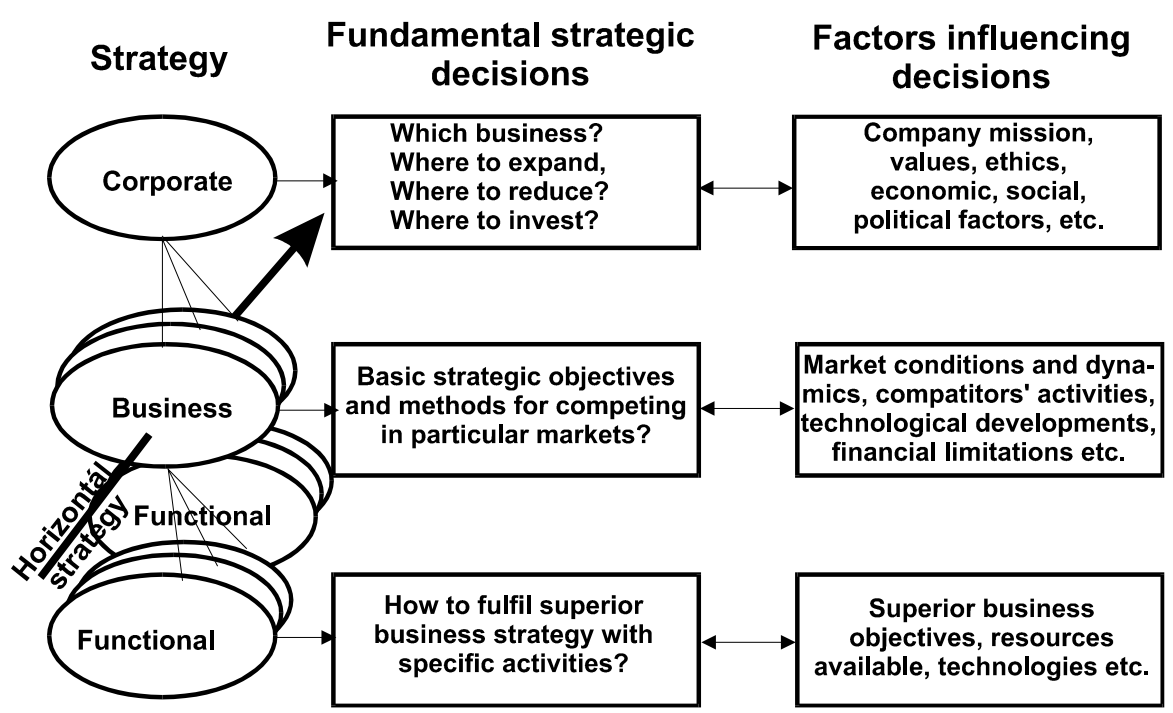

Figure 3: Strategy hierarchy - the concept applied in the research described in this paper Keřkovský and Vykypěl (2006).

\subsubsection{Corporate strategy}

Corporate strategy transforms the mission and vision of the company into basic business decisions and goals, such as in which country and industry to start or continue a business, how to allocate disposable resources, what should be the basic ideas for business management or which of the existing business plans should be preferred. Using Keřkovský and Vykypěl (2006) the corporate strategy can be taken into account as an elaboration of the company's vision and mission in the following three steps:

1. Strategic Business Units ${ }^{1)}$ definition;

2. Designation of the basic strategic targets to the particular SBUs; and

3. Achievement ways specification of designated targets of particular SBUs.

\subsubsection{Business strategy}

Business strategy expresses basic strategic objectives and ways of realising them for a particular SBU. An SBU can be basically defined on the basis of:

1. Organisational approach: Definition of an SBU fits with the existing or proposed organisational structure of the company.

2. Strategic and market approach: In this case one organisational unit can have more than one SBU, i.e., more than one business strategy, or one SBU and its strategy affects more than one organisational unit. The first option can be applied, for example, if the specific type of production or service has specific types of customers with specific needs. The second option can be applied, for example, in the production or service delivery which is a task of the follow-up organisational units.

3. Project oriented: A more flexible variation of the previous approach having a temporary validity due to a limited project duration.

4. Combination of described approaches.

\footnotetext{
$\left.{ }^{1}\right)$ Strategic Business Unit - SBU - is defined by specifying a group of customers and their needs the company or sector intends to satisfy, together with the production technologies used to this end, Kotler (1984) discussed at the specific chapter.
} 
There are several indicators if an SBU has been defined properly:

- Are there specific customers or competitors for a specific area of operation?

- Can specific, different, non-overlapping, and non-competing goals and objectives be defined for designated SBUs?

- Can a specific SBU be cancelled without the necessity of specification changing of others?

\subsubsection{Functional strategy}

For each business strategy or for several business strategies commonly, functional strategies for specific areas should be defined to support and specify it in each field of strategic management. Functional strategy should follow business strategy at a lower level of the hierarchy and set out strategic goals for specific areas in the company in R\&D, quality management system, marketing, HRM, IS/IT, production, and so on. The basic function of this strategy is to ensure the development of strategically important parts of the business in accordance with the company's overall strategic development.

\subsection{Employed methods of analyses}

Corporate, business, and functional strategies should be formulated on the basis of in-depth analyses; the structure of these is displayed in table 1.

Table 1: Table of kinds of employed analyse in the dissertation.

\begin{tabular}{|l|l|c|c|c|}
\hline \multicolumn{2}{|c|}{ Analysis } & Selected Kind of Analyse & Output & $\begin{array}{c}\text { Overall } \\
\text { Output }\end{array}$ \\
\hline \multirow{2}{*}{ External Factors } & General & SLEPT / MAP & \multirow{2}{*}{ ETOP } & \\
\cline { 2 - 3 } & Branch & Porter's Five Forces model & \multirow{2}{*}{ SWOT } \\
\cline { 1 - 3 } Internal Factors & 7 S or 7 P & SAP & \\
\cline { 1 - 3 } Stakeholders & Analyse of stakeholders & SWOT & \\
\hline
\end{tabular}

\subsubsection{General external factors SLEPT}

Acronym SLEPT means analysis of Social, Legal, Economy, Politics, Technology factors, see diagram in Figure 4.

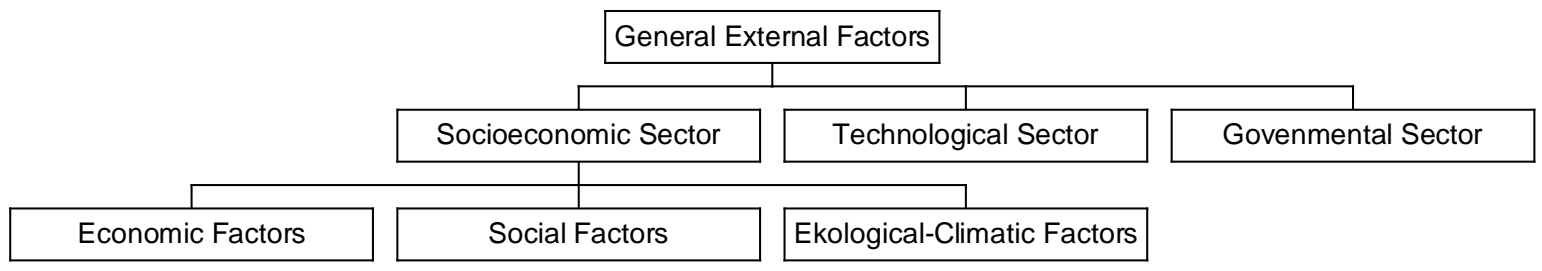

Figure 4: External General Factors (Keřkovský and Vykypěl, 2006). 


\subsubsection{Branch external factors analysis using Porter's Five Forces model}

Porter's Five Forces model, Porter (1985), concentrates analysis of the branch external factors into five groups of forces influencing the behaviour of a company operating in a specific area, i.e.:

- Threat of new competition

- Threat of substitute products or services

- Bargaining power of customers (buyers, users)

- Bargaining power of suppliers

- Intensity of competitive rivalry

As can be seen, only two of Porter's forces are relevant in the case of the highway administration, due to it not having any competitor, substitute, and competitive rivalry. Customer force is employed through stakeholders because customers, i.e., road users can be very powerful stakeholders. The remaining powers, i.e., Suppliers' power, should be deeply analysed.

\subsubsection{ETOP as an output of analyses of external factors}

ETOP (Environmental Threat and Opportunity Profile) is understood as a method for summarising external environment analyses. The results of SLEPT and Porter's analysis are expressed through Opportunities and Threats.

\subsubsection{Analysis of internal factors}

As an ETOP summarizes external environment analyses, SAP (Strategic Advantages Profile) can serve as a summarisation of internal factors analyses. SAP closely relates with the method used for the analyses.

McKinsey's 7 S method of analyse, e.g., according to Rasiel and Friga (2001); The 7 S framework of McKinsey is a Value Based Management (VBM) model that describes how one can holistically and effectively organize a company. The model consists of the following elements:

- Shared Values - the interconnecting centre of McKinsey's model; what does the organisation stands for and what does it believe in. Central beliefs and attitudes;

- Strategy; Plans for the allocation of the firm's scarce resources, over time, to reach the identified goals. Environment, competition, customers;

- Structure; The way the organization's units relate to each other: centralized, functional divisions (top-down); decentralized (the trend in larger organizations); matrix, network, holding, etc.;

- Systems; The procedures, processes and routines that characterize how important work is to be done: financial systems; hiring, promotion, and performance appraisal systems; information systems;

- Staff; Numbers and types of personnel within the organization;

- Style; Cultural style of the organization and how key managers behave in achieving the organization's goals. Management Styles; and

- Skills; Distinctive capabilities of personnel or of the organization as a whole. Core Competences. Well-known. 
Besides the $7 \mathrm{~S}$ McKinsey model the Marketing Mix Model (MMM) in its extended version can be used as analytic tool for an SAP drafting. The extended MMM, as with the $7 \mathrm{~S}$ model, consists of seven components summarising an internal environment, i.e.:

$$
\begin{aligned}
& \text { 1P - Product } \\
& \text { 2P - Price } \\
& 3 \mathrm{P} \text { - Place } \\
& \text { 4P - Promotion } \\
& \text { 5P - People } \\
& 6 \mathrm{P} \text { - Process } \\
& 7 \mathrm{P} \text { - Planning }
\end{aligned}
$$

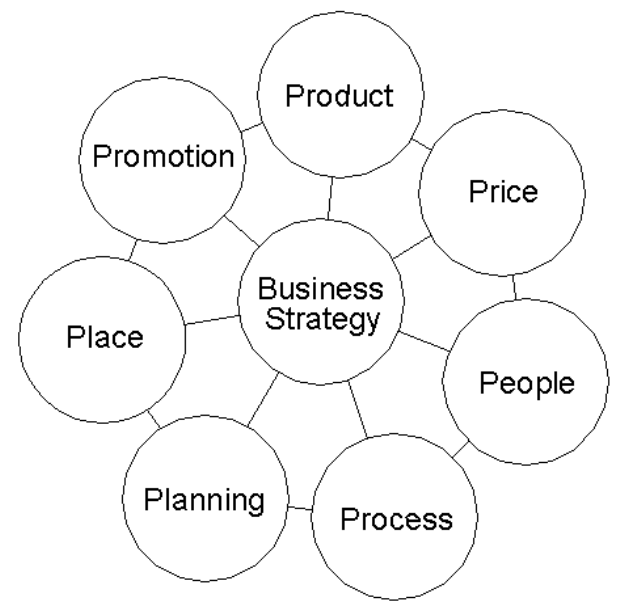

Figure 5: 7P Marketing Mix Model (Keřkovský and Vykypěl, 2006).

If MMM is used as a tool for SAP creation, i.e., for the analysis of a company's internal environment, it results in a company Strengths and Weaknesses definition.

\subsubsection{Analysis of stakeholders}

Analysis of key stakeholders can be done through interviews, meetings, and negotiations with them. It is very sensitive in the case of the highway administration transformation, as the administration works with large amounts of public money, and its operation is subject of public concern, including politicians.

\subsubsection{Summary of analyses as a starting point of strategy formulation}

A summary of analyses carried out can be expressed using a SWOT table, where the analyses of stakeholders, and internal and external factors should be evaluated by their importance. For a strategy formulation it should be known that "each" Strength could be employed, Weaknesses eliminated, Opportunities drawn on, and for Threats remedial measures could be adopted. In a defined case the strategy should be balanced and fit the real environment of the company.

\section{POSSIBLE APPLICATION OF THE DESCRIBED MODEL}

\subsection{Vision and mission}

The vision and mission of the transformed highway administration should be seen as being wider than that of the case of a private company. They have to give answers to crucial and highly important questions and should be drafted after an in-depth discussion with all powerful stakeholders and analyses of their impact. Questions should include the following:

- Which legal status will the transformed organisation have, i.e., state public enterprise or joint stock company?

- Will the transformation be carried out using a special act - lex specialis, which can define the specific parameters and behaviour of the transformed organisation? 
- Will the transformed highway administration include motorways only or first-class roads as well?

- Will lands, pavements, and structures be the property of the transformed organisation or will it have rights for only the management of them?

- Will it be possible to pawn lands, pavements, and structures?

All answers on the above drafted questions are "input parameters" to the corporate strategy and their subordinated business and functional strategies. The input parameters create a foundation for the operation of the future highway administration and have to consulted and verified by all core stakeholders, mainly the representatives of all relevant political parties.

Figure 6 displays the hierarchies of the three-level understanding of strategies and necessary analyses for their formulation.

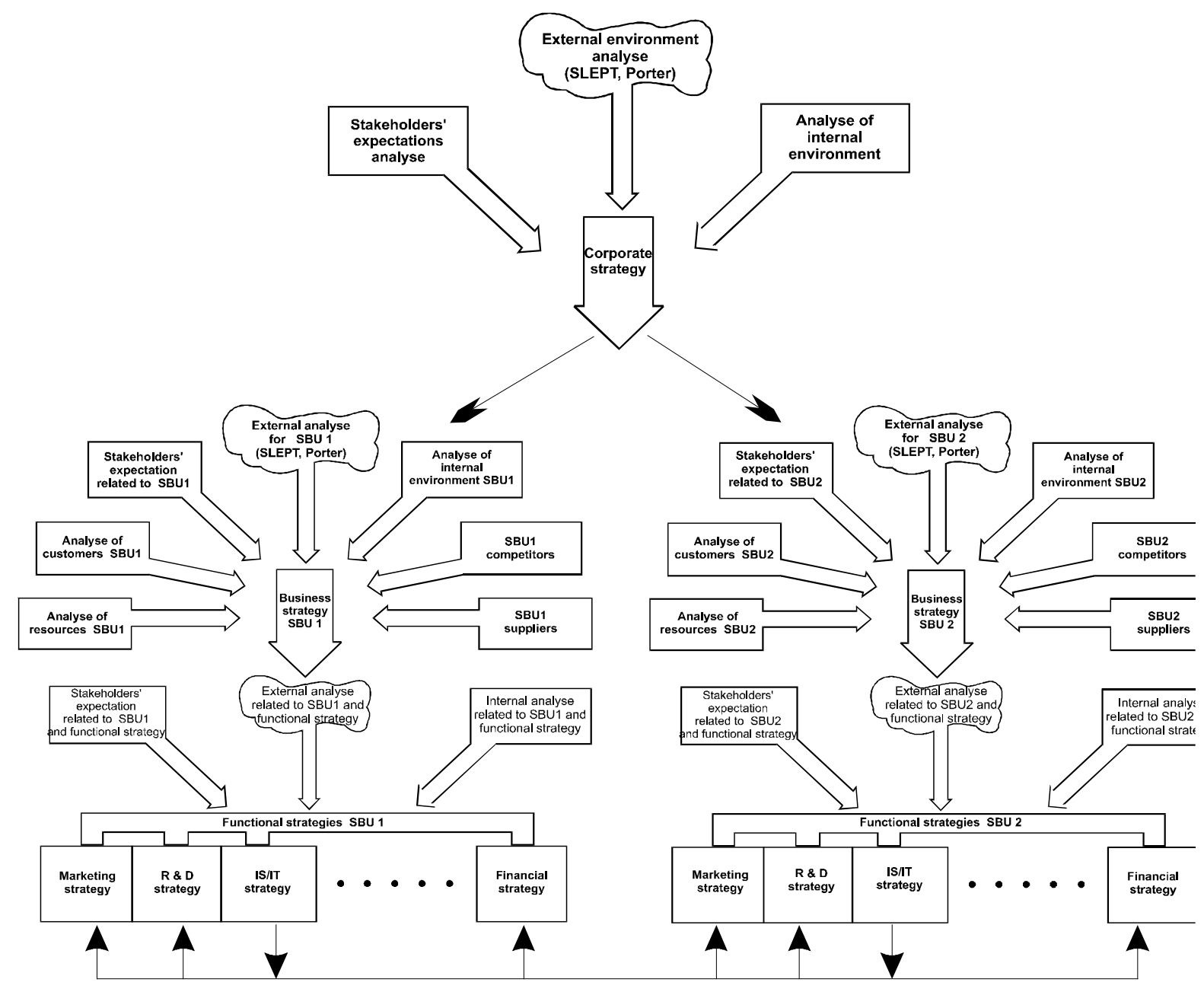

Figure 6: Strategy hierarchies and analyses needed for their formulation (Keřkovský and Vykypěl, 2006). 


\subsection{Corporate strategy}

When the above-mentioned input parameters have been stated, the analyses necessary for the corporate strategy can start. As explained in 3.1.1, the corporate strategy should consist of three components:

- $\quad$ A Strategic Business Units definition which can fit e.g.:

o either types of operation of the highway administration, i.e.:

- SBU 1: Construction

- SBU 2: Maintenance

- SBU 3: Winter maintenance

- SBU 4: Financing (toll collection, bonds...)

Note: If the transformed highway administration covers both motorways and first-class roads, the above drafted structure should be doubled.

o or methods of operation of the highway administration, i.e.:

- SBU 1: Preparation of construction

- SBU 2: Contracting (selection procedures, agreements...)

- SBU 3: Supervision (construction works, completion certificates, evaluation in warranty period)

- SBU 4: Maintenance planning (based on Pavement and Bridge Management Systems)

- SBU 5: Maintenance performing-in-house

- SBU 6: Maintenance performing- outsourcing (contracting and supervision)

- SBU 7: Winter maintenance performing-in-house

- SBU 8: Winter Maintenance performing- outsourcing (contracting and supervision)

- SBU 9: Toll collection

- SBU 10: Other financial sources (bonds, loans, subsidies)

- etc.

- $\quad$ Designation of the basic strategic targets to the particular SBUs, e.g.:

o Number of kilometres of new motorways...

o Level of maintained network quality expressed exactly in...

o Costs of construction works...

Note: Each of the designated targets has to be defined through SMART ${ }^{2}$.

- Achievement methods specification of designated targets of particular SBUs; in the case of the highway administration this could be:

o definition of financing sources,

o definition of limits,

0 etc.

\footnotetext{
${ }^{2}$ SMART is an acronym of Specific, Measurable, Ambitious, Realistic and Time-fixed
} 


\subsection{Business Strategy}

Each SBU has to have its own business strategy. For its formulation analyses can be carried out as described in part 3.2 of this paper. These analyses mostly cannot be elaborated without the support of experts in specific areas, i.e., civil engineers, ITS experts, economic experts, lawyers, etc.

\subsection{Functional strategy}

In effect a functional strategy describes the "how to do it" area. As a corporate strategy states how, for example, toll collection will be carried out, a functional strategy should state, on the basis of in-depth analyses, how much money will be added to the budget of the highway administration or, for example, $R \& D$ will be performed through external bodies, a functional strategy should state how R\&D programs or projects will be formulated, financed, evaluated and their results utilized.

Modern concepts of traffic management are widely supported with intelligent transport systems (ITS). The goal is especially to optimize the movement of vehicles to be smooth and "wring out" hidden highway capacity. The development of ITS is strongly influenced by highway structural parameters, driver behavioural patterns, budget possibilities, and technological development, (for example, in sensors, ways of data collection and its interpretation and delivering to users etc.). All the above-mentioned should be taken into account in the formulation of ITS and relating strategies.

An ITS strategy can be formulated as either a business strategy or functional strategy. This depends on the sense of importance and understanding. The following text assumes the ITS strategy to be a functional strategy supporting the majority of business strategies of a highway administration.

Due to the above-mentioned, an ITS strategy could be seen as a paradigmatic strategy concerning its significance. ITS have a potential of being an opportunity for the transportation sector - a strategic asset, a tool for collecting strategic information regarding highway network development, a tool for raising its effectiveness, quality, flexibility and environmentally friendly impact (Pípa and Plíhal, 2009). Paradoxically, due to the extremely rapid technological progress, the traditional weaknesses of management, where the use of ITS is concerned, are becoming more and more evident. These are especially:

- Improper use of ITS, lack of long-term approach to making decisions about ITS development in the full context of strategic management;

- Poor communication with experts;

- $\quad$ Failure to involve users, failure to exploit the opportunities/potential to the full;

- Insufficient attention to "human factors".

It is also important that ITS are managed effectively at all levels of management the strategic, the tactical, and the operational. There are research and implementation documents targeting the ITS architecture, i.e., Jesty et al. (1998) composed guidelines for the development and assessment of ITS architectures, Ferro et al. (2004), Ortgiese and Escher (2004), Angebaudand and Escher (2005) and Escher and Grammling (2005) published their contributions to specific components of telematic system.

There are several key research documents in the Czech Republic aimed towards ITS in the Czech Republic, i.e., Svítek et al. (2005), which describe the achievements of the R\&D project awarded by the Czech Ministry of Transportation, and Moos and Prribyl (2008) elaborated on comprehensive guidelines for a systematic approach for the application 
of transport-telematic projects. The guidelines describe the best-practice in the design of the above-mentioned systems architecture and tools for architecture creation and are very useful tools for any ITS project elaboration. Pípa et al. (2009) dealt with the relationship between highway design and ITS in an R\&D project of the Ministry of Transport.

The above cited documents take the ITS challenges from both systemic and technical points of view. Strategic management can affect them either positively or negatively, as well as tactical and operational management.

\section{CONCLUSION}

The introduced concept of strategic management discussed in the paper is the result of research based on a confrontation of the study of fundamental literature on strategic management and an experience of the practice of strategic management and the functionality of the Czech transport sector. The transformation of ŘSD, the highway administration, is a fundamental act which could have a very promising impact on the functionality and effectiveness of the highway administration. A presumption of a positive opportunity of the highway administration's legal status change is its substantial preparation supported by in-depth analyses and high-quality design of strategies at all three described levels. If the legal status change is only a formal change, the "new" organisation will assume the defects and flaws of the "old" one.

\section{REFERENCES}

Angebaud, D. and Escher, A., 2005. Global System for Telematics: DEL_EFCD_3_1 Architecture and Interface Specifications. PTV AG, ERTICO.

Dobson, P. and Starkey, K., 1993. The Strategic Management Blueprint. Oxford: Blackwell Business. 161 p. ISBN 9780631186243.

Escher, A. and Grammling, M., 2005. Global System for Telematics. DEL_EFCD_3_2 Reference Implementation. PTV AG, ERTICO.

Ferro, F. et al., 2004. Global System for Telematics. IP High Level Architecture. Motorola, ERTICO.

Jesty, P. H. et al., 1998. CONVERGE - TR 1101 - Guidelines for the Development and Assessment of Intelligent Transport System Architectures. Report of Work-Package SA2\&3 [online]. Retrieved from:

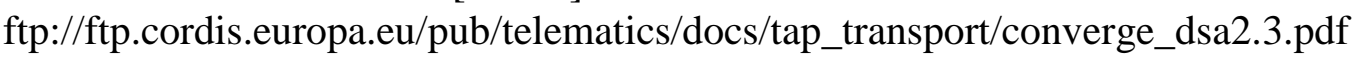

Johnson, G. and Scholes, K., 1993. Exploring Corporate Strategy: Text and Cases, 3rd edition. New York: Prentice Hall. ISBN 987-0132974417.

Keřkovský, M. and Vykypěl, O., 2006. Strategické ř́zení: teorie pro praxi. Praha: C.H. Beck. 206 p. ISBN 80-7179-453-8. (in Czech)

Kotler, P., 1984. Marketing Management. New York: Prentice Hall (Engelwood Cliffs, N. J.). ISBN 0135579279. 
Moos, P. and Přibyl, P., 2008. Tvorba systémového projektu dopravně-telematických aplikací: Metodický pokyn [Creation of Traffic-Telematic Application System Project: Guidelines]. Praha: Czech Technical University. (in Czech)

Nickols, F., 2000. Three Forms of Strategy Corporate, Competitive and Strategy in General [online]. Retrieved from: http://home.att.net/ nickols/strategy_forms.htm

Ortgiese, M. and Escher, A., 2004. Global System for Telematics. DEL_EFCD_2_1 Use Cases and System Requirements. PTV AG, Ertico.

Pípa, M. et al., 2009. Projektování silnic a dálnic s ohledem na ITS systémy, projekt MD. [Roads and highways design reflecting ITS, R\&D Project of the Czech Ministry of Transport, Research report]. Brno: Centrum dopravního výzkumu, v.v.i. (in Czech)

Pípa, M. and Plíhal, J., 2009. Novou výzvou je komunikace mezi vozidly a infrastrukturou. [Vehicle infrastructure integration is a new challenge]. Dopravní noviny, vol. 18, no. 30, p. 3. ISSN 1210-1141. (in Czech)

Porter, M. E., 1985. Competitive Strategy. New York: Macmillan.

Porter, M., 1996. What is Strategy? Harvard Business Review, November-December 1996, pp. $61-78$.

Rasiel, E. M. and Friga, P. N., 2001. The McKinsey Mind: Understanding and Implementing the Problem-Solving Tools and Management Techniques of the World's Top Strategic Consulting Firm. New York: McGraw-Hill. 272 p. ISBN 978-0071374293.

Svítek, M. et al., 2006. ITS v podmínkách dopravně-telematického konceptu České republiky, projekt MD [ITS in condition of the traffic-telematic concept of the Czech Republic, $R \& D$ Project of the Czech Ministry of Transport, Research report]. (in Czech)

\author{
The article was produced under the support of the project \\ Transport R\&D Centre (CZ.1.05/2.1.00/03.0064).
}




\section{Instructions to the authors}

\section{GENERAL GUIDELINES}

Papers based on accepted abstracts and prepared in accordance to these guidelines are to be submitted through the journal's web site www.transportsciences.org. All papers, using Microsoft Word2000 (or newer) are limited to a size of at least 4 and no more than 8 single-spaced pages on A4 paper size (297 mm X $210 \mathrm{~mm}$ ), including figures, tables, and references and should have an even number of pages. The paper's top, bottom, right and left margins must be $2.5 \mathrm{~cm}$. No headers, footers and page numbers should be inserted.

\section{TITLE, AUTHORS, AFFILIATIONS}

The title of the paper must be in title letters, Times New Roman, font size 16, and aligned left. Use more than one line if necessary, but always use single-line spacing (without blank lines). Then, after one blank line, aligned left, type the First Author's name (first the initial of the first name, then the last name). If any of the coauthors have the same affiliation as the first author, add his/her name after an \& (or a comma if more names follow). In the following line type the institution details (Name of the institution, City, State/Province, Country and e-mail address of a corresponding author). If there are authors linked to other institutions, after a blank line, repeat this procedure. The authors name must be in Times New Roman, regular, and font size 12. The institution details

must be in Times New Roman, italic, and font size 10.

\section{ABSTRACT}

The abstract should start after leaving eight blank lines. Type the text of the abstract in one paragraph, after a space behind the word abstract and colon, with a maximum of 250 words in Times New Roman, regular, font size 12, single-spaced, and justified. After leaving one blank line, type KEY WORDS: (capital letters, Times New Roman, font size 12), followed by a maximum of five (5) key words separated by commas. Only the first letter of the first key word should be capitalized.

\section{THE TEXT}

The main body of the paper follows the key words, after two blank lines (i.e., two blank lines between the first heading and the key words). The body text should be typed in Times New Roman, font size 12 and justified. The first line of the paragraphs should be indented $5 \mathrm{~mm}$ except the paragraphs that follow heading or subheading (i.e., the first line of the paragraphs that follow heading or subheading should not be indented). Never use bold and never underline any body text.

\subsection{HEADINGS AND SUBHEADINGS}

The headings are in capital letters, Times New Roman, font size 12. Subheadings are in title letters Times New Roman, font size 12. The headings and subheadings must be aligned left and should not be indented. Leave two blank lines before and one after the heading. There should be one (1) blank line before and after the subheadings. All headings and subheadings must be numbered. If a heading or subheading falls at the bottom of a page it should be transferred to the top of the next page.

\subsection{FIGURES AND TABLES}

Figures, line drawings, photographs, tables should be placed in the appropriate location, aligned centre, and positioned close to the citation in the document. They should have a caption, Times New Roman font size 12, with a colon dividing the figure number and the title (Figure 1: Material properties) and should be numbered consecutively, e.g. Figure 1, Figure 2, Table 1, and Table 2.

\subsection{REFERENCES}

At the end of the paper, list all references with the last name of the first author in alphabetical order, underneath the heading REFERENCES, as in the example. The title of the referred publication should be in italic while the rest of the reference description should be in regular letters. References should be typed in Times New Roman font size 12. citation standard ISO 690.

More details can be found at www.transportsciences.org. 